\section{A HASZNÁLATALAPÚ BIZTOSÍTÁS MÚLTJA, JELENE ÉS JÖVŐJE}

A Deloitte munkatársai: Hauer Judit (Senior Manager), jhauer@deloittece.com, Góg Enikő (Manager), egog@deloittece. com; Horváth András (Manager), Hrabár Ádám (Manager), ahrabar@deloittece.com, Pálinkás Klára (Senior Consultant), KPalinkas@deloittece.com,Urbán Dóra (Consultant),durban@deloittece.com,

\section{ÖSSZEFOGLALÓ}

A cikk részletesen ismerteti a használatalapú biztosítás (Usage-Based Insurance, UBI) fejlődését, helyzetét a nemzetközi és a magyar piacon. Minden esetben elmondható, hogy a biztosítók igyekeznek a rendelkezésre álló különböző technológiák közül ügyfeleik számára a legmegfelelőbbet kínálni. A megfelelő technológiai megoldás kiválasztásában a demográfiai sajátosságok és a fogyasztói elvárások nagy szerepet játszanak, alkalmazásuk az egyes országokban és adott országon belül biztosítónként is eltérő lehet, az árképzéssel és a kínált szolgáltatásokkal egyetemben.

\section{SUMMARY}

Telematics has enjoyed enormous attention in the auto insurance market in recent years. The goal is to capture and analyze data on customers' actual driving behavior to write Usage-Based Insurance, UBI more effectively. Telematics makes use of satellite and/ or cellular technologies, along with a standalone device, the car's computer and mechanics or a mobile app. The outcome is that insurance rates, deductibles and coverage features can be defined based on actual usage and driving practices, by using indicators of actual risk.

UBI seems to be a true, growing market potential in the US and several European countries, however in Hungary it is still in early stage.

- Based on estimations global premium income of telematics products can reach 50 billion USD by 2020 and number of contracts can rise up to 100 billion (in Europe to 28.1 billion).

- The spread of telematics services is supported by regulatory decisions such as gender equality in risk calculation and obligatory application of an e-Call system to every vehicle manufactured after March 2018.

The article covers important aspects of the potential of UBI, including background, opportunities and potential competitive threats behind.
Kulcsszavak: használatalapú biztosítás, innováció

Key words: usage-based insurance, innovation

JEL: G22, O30

DOI: $10.18530 /$ BK.2017.2.22

http://dx.doi.org/1018530/BK.2017.2.22

A használatalapú biztosítás egy telematikai berendezés segítségével monitorozza és tárolja a biztosított autó vezetés közben gyüjtött kvantitatív, illetve kvalitatív adatait. Ez a fajta megközelítés jelentős piaci résnek bizonyul az Egyesült Államok és számos európai ország biztosítási piacán, míg Magyarországon az ilyen típusú biztosítási formák kifejlesztése és megvalósítása jelenleg még gyerekcipőben jár. A Deloitte összefoglalta a jelenség okait, szakmai körülményeit és jövőbeni kilátásait.

Azok a biztosítók, amelyek időben lépnek, és tervezik meg UBI-programjukat, jelentős piaci előnyre tehetnek szert, mivel első kézből származó információval rendelkeznek majd az ügyfeleik vezetési mintájára vonatkozóan. A megfelelő adatok begyűjtése ugyanis lehetővé teszi biztosítottjaik vezetési szokásainak elemzését, támogatva a biztosítási termék árazásának és pozicionálásának pontosabb módszertanát.

Azok a biztosítók, amelyek időben lépnek, és tervezik meg UBI-programjukat, jelentős piaci előnyre tehetnek szert.

Az autókba épített telematikai berendezésnek, a rendszer által monitorozott és összegyüjtött adatoknak köszönhetően különbséget tud tenni két, hasonló biztosítási csomaggal rendelkező vezető között: ha az egyik tizedannyi utat tesz meg, mint a másik, vagy kevésbé zsúfolt időszakban vezet, a biztosítónak lehetősége van a tapasztalati információk alapján a kockázatot pontosabban behatárolni, így a fennálló kockázatnak megfelelőbb árat meghatározni a biztosítottak számára.

A kárrendezési folyamat átalakulása további előnyökkel is járhat: a káresemény bekövetkeztét a gyorsulási adatok (pl. gravitációs erő, fékerő) hirtelen változásából a berendezés azonnal képes jelezni, amire azonnal reakció adható a biztosító részéről (például SMS küldése az ügyfél számára az esetleges probléma megoldására, rendőrség értesítése a gépjármű ellopása esetén, segélyhívás indítása baleset esetén, stb.) Ezáltal a kárbejelentési folyamat lerövidülhet, a biztosító kárrendezési folyamata pedig optimalizálhatóvá válik - arról nem is beszélve, hogy a gyorsabban továbbított segítségnyújtás sok esetben akár életeket is menthet. Az UBI-szisztémájú biztosítás a biztosítók kárráfordítására is pozitív hatással lehet, hiszen a rögzített adatok alapján 
visszaellenőrizhetőek lesznek a valós és valótlan károk, esetleges biztosítási csalások.

\section{Az UBI-szegmens}

A használatalapú termékek a gépjármü-biztosítások jelenleg leggyorsabban növekvő szegmensét jelentik világszerte. Egyes becslések szerint 2020-ra a telematikai típusú termékekből származó díjbevétel globálisan elérheti az 50 milliárd dollárt, a szerződések száma pedig a 100 milliós darabszámot. ${ }^{1}$ Az elmúlt évek tendenciáját követő globális díjbevétel-növekedés túlnyomó részét a fejlődő régiók jelentős megerősödése, illetve a jelenleg is élenjáró Észak-Amerika és Európa piacai fogják leginkább kitenni. Az Egyesült Államok és Európa nyugati országai egyaránt a legfejlettebb használatalapú biztosítási piacokkal rendelkeznek. A használatalapú gépjármü-biztosítási termékek elterjedésének és ezzel párhuzamosan fejlesztésének ütemét jól mutatja az a tény, hogy míg 2013-ban 17 országban 155 aktív UBI termék volt elérhető világszerte, addig 2015 végére már 34 országban 204 darab használatalapú gépjármü-biztosítási terméket lehetett beazonosítani. ${ }^{2}$

A különböző piacokon a biztosítók által használt telematikai termékekhez kínált eszközök széles választéka alakult ki, amelyek közül a klasszikusoknak számító „black box" és OBD dongle berendezések mellett a folyamatos innovációnak köszönhetően az autókba szerelt rendszerek és az azokkal együtt, illetve önállóan is müködtethető mobil applikációk tekinthetők a legelterjedtebbnek. A különböző telematikai eszközök rövid jellemzései alább találhatóak:

- OBD-II: az OBD egy olyan, számítógép-alapú rendszer, amely a motor fö alkatrészeinek, illetve a károsanyag-kibocsátásnak az ellenőrzésére lett tervezve. Az OBD-II az Egyesült Államok Környezetvédelmi Ügynökségének (EPA) sztenderdjei alapján kialakított felület, amelyhez a fedélzeti számítógéppel érintkező eszközöket lehet csatlakoztatni.

- Black box: az egyik legbiztonságosabb és egyben legdrágább megoldás a magas telepítési és adminisztrációs költségek miatt. Az autók motorja mellé elhelyezett berendezésről van szó, amely önmagában és mobil alkalmazással együtt is tudja gyüjteni és követni a vezetési adatokat. Főként Európában népszerű megoldás.

- Autókba szerelt rendszerek: az autók motorvezérlő egységeihez csatlakoztatott modulok, amelyeket eredetileg navigáció (az autó helyzetének megállapítása), kulcs nélküli nyitás/zárás (pl. kulcs autóban felejtése esetén), az autó diagnosztikai állapotára vonatkozó adatgyüjtés, illetve szórakoztatóelektronikai szolgáltatások (pl. sporthírek, időjárás-jelentés) céljára használtak. Az effajta rendszerek használata általában havi díj fizetésével lehetséges, ami a többi megoldással szemben magasabb ügyfélköltséget eredményez. Ezek a termékek leginkább a mobil applikációval történő közös alkalmazás miatt váltak népszerűvé a piacokon.
- Mobil alkalmazás: a legegyszerübbnek és a leginkább költségkímélőnek tekinthető megoldás, mivel a mobiltelefonok már önmagukban rendelkeznek a legtöbb szükséges funkcióval (pl. GPS, giroszkóp, gyorsulásmérő, nagy adattárolási kapacitás), és a telepítési költségei minimálisak a biztosítók és az ügyfelek számára egyaránt. Használatához csupán egy alkalmazás letöltésére van szükség, amelyen az ügyfél a vezetési szokásait tudja figyelemmel kísérni. Megkülönböztetője a többi megoldáshoz képest, hogy ebben az esetben csakis a vezetési szokásra vonatkozó információk válnak elérhetővé és elemezhetővé, az autó állapotára vonatkozók nem. Bár a tendenciák ebbe az irányba mutatnak, előnyei ellenére mégsem terjedt még el széles körben, mivel a telefonok által gyűjtött és feldolgozott adatok nem mindig a legmegbízhatóbbak és legjobb minőségűek.

\section{A Deloitte felmérése}

A Deloitte New York-i irodájának előzetes feltevése, miszerint csak bizonyos társadalmi szegmensek fognak kedvezően reagálni erre az újfajta biztosítási lehetőségre (vagyis hajlandóak lesznek a vezetési stílusukról és minden egyéb adatukról - megtett út, átlagfogyasztás, teljes fogyasztás, vezetési idő, GPS koordináták stb. - adatot szolgáltatni a biztosító felé), a tanácsadó cég 2014 januárjában folytatott felmérése alapján beigazolódott. ${ }^{3}$ A felmérés a mobil technológiával kapcsolatos tapasztalatokat, a fogyasztói felfogást és elvárásokat gyüjtötte össze a biztosítási szolgáltatások fogyasztói között. 2193 föt kérdeztek meg változó demográfiai és jövedelmi háttérrel. Többek között azt vizsgálták, hogy a megkérdezettek a mobiltelefonon elérhető alkalmazást, avagy a gépjárműbe beépített telematikai berendezést preferálják-e, esetleg olyan gépjármű megvételét, amelyben a gyártó maga gondoskodik a berendezés beszereléséről.

A felmérés alapján az életkor bizonyult a legjelentősebb vízválasztó tényezőnek: a 21-29 éves korúak kétharmada lenne hajlandó mindezt kipróbálni, és engedni, hogy vezetési szokásait megfigyelje a biztosító.

A Deloitte csapata a fenti felmérésen kívül két pilot projektet is sikeresen zárt: ${ }^{4}$

a. Mobiltelefonos próbaalkalmazáson keresztül 60-90 napig monitoroztak GPS-adatokat. Ezzel a módszerrel információt tudtak gyüjteni a vezetési élményről, hogy megtalálják a város azon pontjait, kereszteződéseit, amelyekben jellemző a nem biztonságos vezetés. Az adatokat átadták egy biztosítótársaságnak, akik így be tudták azonosítani a területi kockázatokat.

b. Mobiltelefonos alkalmazáson keresztül figyelték a telematikai módszert, és pontrendszert állítottak fel a vezetési szokásokra (100 - tökéletes, 50 - jó, 20 - rossz). A vezetők így nyomon tudták követni a saját egyéni pontszámaikat minden megtett út után. Ezután 60-90 napos periódusokban vizsgálták, hogy javultak-e a vezetési szokásaik. ${ }^{5}$

Az Egyesült Államokban a legtöbb UBI-biztosítással rendelkező ügyfélnek utólagosan be- 
szerelt telematikai eszközzel monitorozzák a vezetési magatartását. A mobileszközre telepített alkalmazás használata csökkentheti a biztosító azon költségeit, amelyek közvetlenül a berendezés allokálásához és visszakereséséhez, az adatátvitelhez és a technológiához kapcsolódnak.

\section{Lehetőségek a vásárlók megtartására}

A biztosító legfőbb érdeke, hogy megfelelő mennyiségű és minőségű adatot halmozzon fel, elősegítve ezzel a pontosabb árazási és prediktív modellezés fejlesztését. Az Egyesült Államokban, motivációs erőként, több biztosítótársaság is dijjengedményt nyújt az ügyfeleknek pusztán az UBI-programban való részvételért. Ez jelenti a biztosítás megkötésére irányuló ösztönzőt és a telematikai eszköz által továbbított információáramlás ellenértékét is.

\section{Az Egyesuilt Államokban több biztosítótársaság is díjengedményt} nyújt az ügyfeleknek pusztán az UBI-programban való részvételért.

Azok az intézmények, amelyek az elsők között vezetik be ezt a terméket a piacra, a termék használatának korai szakaszában kissé veszíthetnek a profitjukból. A díjengedményekkel azonban (amelyeket a bekerülési költség részeként is felfoghatunk) új ügyfeleket érhetnek el, és további értékes adatokat gyüithetnek a meglévő ügyfelektől. Ezen túlmenően a telematikai berendezés segítségével szerzett információk alapján a biztositók javíthatják a szegmentációjukat, biztosítási és árazási megfelelőségüket, ami hosszú távon szintén javíthatja a nyereségességet. A termék felfutásának korai szakaszában a kedvezmény még elégséges lehet a piaci részesedés növeléséhez, de amint a piac telítetté válik, a biztosítóknak más módszerrel is meg kell tartaniuk a meglévő ügyfeleiket. Márkahüség kialakítása csak az ügyfelekre fordított folyamatos figyelemmel lehetséges, amire az alábbi javaslatokat adja a New York-i Deloitte kutatói csapatának cikke ${ }^{6}$, amely az amerikai piacon meglévő biztosítói tapasztalatokon nyugszik:

- azonnali visszajelzés az ügyfél számára arról, hogy miként javithat vezetési szokásain, biztonságosabbá téve ezáltal a közlekedést;

- lehetséges veszélyekről szóló azonnali értesítés (veszélyes vagy csúszós utak, útfelbontások, balesetek stb.);

- baleset esetén közvetlen kárbejelentés;

- a gépjármű meghibásodása esetén assistance szolgáltatás nyúitása;

- elveszett, illetve ellopott gépjármü felkutatása;

- ún. „geo-fencing”, amely lehetőséget ad a szülők számára a gépjárművet használó gyermek útvonalának és vezetési magatartásának nyomon követésére, de hasonló szolgáltatás kérhető idősödő gépjárművezetők esetében is;

- $\quad$ specializált telematikai berendezés segítségével mérhetővé válik a gépjárműnek és soförjének környezetre gyakorolt hatása (ökológiai lábnyoma);

- a program játékosítása (ún. „gamifying”): interaktív módon kapcsolja be a fogyasztót a mérési folyamatba (például saját vagy a biztosítással rendelkezőkhöz, múltbeli teljesítményhez képesti összemérhetőség, fejlődés nyomon követése);

- $\quad$ heti vagy havi versenyzési lehetőség családtagok vagy ugyanannál a biztosítónál szerződéssel rendelkezők között;

- telematikai berendezés megfigyelése alapján - amikor a fogyasztó a kockázatot csökkentvén biztonságosabban, a sebességkorlátozást betartva vezet - hüségpont jutalom;

- $\quad$ szolgáltatókkal (pl. autójavító műhelyekkel, autómosókkal, benzinkutakkal) való szoros együttmüködés

Mindezek által a biztosításnak a megszokott, utólag reagáló és kárkifizetést csökkentő modellje sokkal inkább egy preventív, a fogyasztó kármegelőző vezetési magatartását ösztönző modell felé mozdítható el.

\section{Kihívások}

A termék iránti ellenszenv egyik oka a túlságosan szerteágazó, sokrétű adatszolgáltatás lehet, amely akár a fogyasztók személyiségi jogainak megsértését is súrolhatja. A másik a rögzített adatok harmadik személynek történő kiadása (legyen az hatósági szerv vagy egyéb intézmény).

Az adatgyüités gazdaságos és hatékony módja is további kihívásokat rejthet. Az is kérdéses, hogy a megfelelő mennyiségű elemezhető adat összegyüjtése mekkora nehézséget jelent a biztosítók - különösen a kisebbek - számára. Az Egyesült Államokban nagy általánosságban elmondható, hogy többnyire nagy, multinacionális, nemzeti és államilag is támogatott társaságok vezetnek be hasonló termékeket. Az okostelefonokra letöltött applikációk használata azonban részben megoldhatja a telematikai berendezés beszerelési nehézségeit, egyben a költségeket is csökkentheti.

\section{A hazai helyzet}

A telematikai szolgáltatások biztosításokkal történő kombinációja, a pozitív külföldi példákkal ellentétben, Magyarországon még nem terjedt el a lakosság körében. Egyes hazai biztosítók azonban tisztában vannak azzal, hogy a gépjármü-biztosítások jövőjét ez a technológia jelentheti, így legtöbben igyekeznek is biztosításaik széles palettáját ezzel az újítással kiegészíteni. A közelmúlt számos, telematikát érintő technológiai fejlesztésének köszönhetően a potenciális ügyfelek a hazai biztosítók különböző kínálatából választhatnak egyéni preferenciáik alapján.

A 2009-es évben az UNIQA Biztosító bevezette a gépjármü-biztosítások (casco) mellé kiegészítő biztosításként köthető SafeLine Assistance szolgáltatást. ${ }^{7}$ A pozicionálás során olyan jövőbeni ügyfeleket céloztak meg, akik magas biztonságtudattal rendelkeznek, keveset vezetnek, az arányos díjazást preferálják, és fontosnak tartják a segítségnyújtás gyorsaságát. A technikai feltételek közé tartozik, hogy a gépjármübe be kell építeni a telematikai szerkezetet, mely az adatok mérését végzi, és ezt össze kell kötni az autó utasterében található 
pánikgombbal, melynek használatával veszély esetén azonnali segítséget hívhatunk. A „pay as you drive" modell mellett a telematika alkalmazása lehetővé teszi, hogy lopásvédelemmel is ellássuk autónkat, lopás bekövetkezte esetén követhessük annak útvonalát, illetve baleset bekövetkeztekor azonnali segítséget kaphassunk. A díjazás tartalmazza a készülék árát és annak beépítési költségét, valamint a telematikai szolgáltatás havi díját.

A berendezés az Octo Telematics S.p.A. tulajdonát képezi, és a gépjárműbe történő beépítés napjától határozatlan időre a szerződő használatába kerül. A biztosító működteti a berendezést, és viseli a szolgáltatásnyújtásra vonatkozó telekommunikációs költségeket. Az ügyfél a berendezéssel (a gépjárművezető személyétől függetlenül minden járműhasználat során) rögzített adatok kárrendezési folyamatban való felhasználásába beleegyezik. (Ilyen adatok a futásteljesítmény, érintett úttípus, jármühasználat időszaka és napszaka.)

Technikailag egyszerűbb megoldást kíván az autódiagnosztikai csatlakozóhoz illeszthető készülék, melyet a Vemoco forgalmazásában a Posta Biztosító kínál az ügyfelek számára telematikai szolgáltatás nyújtásához. (A szolgáltatás itt is csak casco mellett vehető igénybe.) A készülék beszerelése annyira egyszerü, hogy azt az ügyfél saját maga is képes végrehajtani. A csatlakoztatott készülék méri többek között a sebességet, az autó kanyarodását, fékezését, elindulását, gyorsaságát, és a mért értékek alapján felállítja a Vemoco-indexet. Ez a mérőszám határozza meg a vezetési stílust, mely az alapját képezi a díjszabási rendszernek. Amennyiben az index az ideális értéken belül marad, úgy a biztosított jó vezetési stílusáért akár 40 százalékos casco-kedvezményben is részesülhet. A biztositás dijával kapcsolatban a biztosító negyedévente felülvizsgálatot végez, melynek során a vezetési adatok kielemzése is megtörténik.

A szolgáltatás mellé okostelefonos applikációt is fejlesztettek, melyen keresztül ugyanúgy nyomon lehet követni a telematika által mért föbb statisztikai adatokat. Az egyik telefonos szolgáltatóval kötött megállapodásnak köszönhetően a telefon SIM-kártyája külföldi tartózkodás esetén is hazai árak mellett küldi az adatokat a Vemoco központjába. A biztosítók csak a kiszámított index-számot kapják meg, a többi adatot bizalmasan kezelik, csak a Vemoco központjában láthatják, illetve onnan továbbítják a szolgáltatást igénybe vevők felé.

\section{Egyéni nyugdíjstratégiák}

Az okostelefonokban rejlő potenciált és a telematikai szolgáltatások alapötletét ötvözve az Aegon Biztosító 2015 második felében bevezette a smartCASCO terméket, mely lehetővé teszi a teljes ügyintézés telefonos applikációval történő lebonyolítását, ideértve a biztosítási ajánlat tételét, a szemlefotók elkészítését, a dífizetést, valamint a szerződés alakulásának nyomon követését is. A telefon segítségével az ügyfél maga állítja be, hogy az autó álló vagy mozgó üzemmódban van, erről az androidos készülékekre Bluetooth kapcsolat útján külön emlékeztető is érkezik. A biztosítás mindenkori díja a tényleges és aktuális kockázathoz igazodik: a gépjármü álló, illetve mozgó üzemmódjától, valamint az éppen igénybe vett kiegészítő biztosításoktól függően változik. A kiegészítő biztosítások összetétele a szerződés hatálya alatt is módosítható.
Mozgó üzemmódban a gépjármüben lévő telefon GPS jeladását aktív állapotban kell tartania az ügyfélnek. A biztosítás „,eltöltős”, azaz addig áll fenn a biztosító kockázatviselése, ameddig arra az elöre befizetett díj fedezetet nyújt. Az ügyfél telefonon a biztosítás hatálya alatt (akár többször) is feltöltheti, és pontosan nyomon követheti egyenlegét. A területi hatály a cascóknál szokásos (azaz lényegében véve Európa). Sajátos rugalmasságot nyújt a terméknek a díj használattól függően változó jellege, valamint az a tény, hogy (a feltöltés mértékétől függö biztosítói fedezetvállalás okán) a szerződő részéről nincs szükség egy teljes évre való elköteleződésre, azaz a szolgáltatás rövidebb időszakokra is igénybe vehető.

Minden esetben elmondható, hogy a magyarországi piac mérete miatt a tapasztalatok egyelöre elenyészőek a telematikai szolgáltatások területén. A kiegészítő szolgáltatás csak casco mellé köthető, mivel a kgfb szigorú szabályrendszere ezt kevésbé teszi lehetővé. A hazai piacon uralkodó erös díjverseny mellett nehéz a megfelelő kedvezmények biztosítása, valamint az ügyfelek hajlandósága a telematikai szolgáltatáshoz szükséges speciális készülék árának megfizetésére is alacsony.

A magyarországi piac mérete miatt a tapasztalatok egyelőre elenyèszőek a telematikai szolgáltatások területén.

Igaz ugyanakkor, hogy a marketingtevékenység egyik biztosító esetében sem volt jelentős, így azután a jelenlegi, viszonylag csekély mennyiségü, telematikát használó ügyfélkör bővítése teljes mértékben elérhető cél lenne. Egyértelmű, hogy az ezen a területen rejlő lehetőségek nincsenek megfelelően kiaknázva, de átfogó kép nélkül nehéz megnyerni a piacot egy még nem elterjedt szolgáltatással. Valószínűleg a hazai járműpark összetétele és az autóimportálási lehetőségek magas kihasználtsága, a lakosság árérzékenysége és a jelenlegi hazai biztosítási dijak szintje mind olyan indokok, melyek egyelőre hátrányosan befolyásolják a telematikai szolgáltatások terjedését. Mindazonáltal megfelelő piackutatással meg lehetne találni azt a megoldást, mely a lakosság igényeit leginkább kiszolgálja. Erre akár a flottákat használó vállalatok is biztosíthatnának alkalmas tesztkörnyezetet. A telematikai megoldások biztosításokkal történő ötvözése tehát remek elgondolás, mely a megfelelő technikai feltételek igénybevétele, a biztosítók és ügyfelek számára egyaránt kifizetődő díjazás kialakítása mellett, népszerű szolgáltatási formaként lenne értékesíthető a magyarországi biztosítási piacon is.

\section{Amerikai Egyesült Államok}

A gépjármű-biztosítási piac a maga 170 milliárd dolláros díjbevételével ${ }^{8}$ az Egyesült Államok biztosítási piacának legnagyobb szegmense, amely az elmúlt években tapasztalt piaci versenynek, illetve az egyre biztonságosabbá váló - és ezáltal a kedvezmények miatt alacsonyabb díjbevételt generáló - közlekedésnek köszönhetően nem tudott jelentős díbevétel-növekedést produkálni. A kiélezett versenyben a piaci szereplők minden új, innovatív megoldásra fogékonyak voltak az ügyfelek lemorzsolódásának megállítása érdekében, ami 
a használatalapú gépjármü-biztosítások gyors fejlődéséhez és elterjedéséhez vezetett. Az Egyesült Államok biztosítási piaca a telematikai típusú gépjármü-biztosítási termékek piacának fejlettségét és az értékesített termékek darabszámát tekintve világviszonylatban is az élvonalba sorolható. Ez többek között annak is köszönhető, hogy a világon az USA biztosítási piacán az elsők között jelentek meg a telematikai típusú termékek: 1997-ben jelentek meg és indultak el a különböző használatalapú gépjármü-biztosítási termékek fejlesztései, amelyek többek között a pénzügyi válság utáni bizonytalanság hatására felerősödött megtakarítási hajlamnak köszönhetően egyre nagyobb népszerűségnek örvendenek. Ezt a fejlődést támasztja alá az a tény is, hogy 2012-ben a legnagyobb biztosítók már több mint fele kínált telematikai megoldásokat. ${ }^{9}$

Az USA-ban nehezíti a piacra lépést, hogy az egyes államok esetében eltérő jogszabályok vannak érvényben a használatalapú termékek értékesítésére vonatkozóan, amelyek magasabb költségek mellett sok esetben operációs akadályokat tudnak állítani az államokon átívelő szolgáltatást nyújtó biztosítók számára.

A telematikai típusú termékekhez kínált eszközök tekintetében az USA-ban elsőként az OBD-II dongle típus terjedt el. Mivel a Clean Air Act 1990-es módosításainak köszönhetően 1995-től minden újonnan gyártott autó automatikusan OBD-II csatlakozóval lett felszerelve, ez a költséghatékony megoldás (elvégre az ügyfél maga csatlakoztatta a berendezést az autóhoz) népszerűvé tudott válni nemcsak a magas díjazású, de az átlagos ügyfelek körében is. Az ügyfél által az autókhoz csatlakoztatandó eszközök mellett napjainkban az autókba integrált rendszerekkel kommunikáló, vezeték nélküli megoldások kezdenek egyre népszerűbbé válni. Ezt támasztja alá az iSuppli 2011-ben készített elörejelzése is, miszerint 2018 végéig a beépített telematikai rendszerrel gyártott gépjárművek aránya az utakon közlekedő autókon belül el fogja érni az Egyesült Államokban a 80, míg globálisan a 46 százalékot. ${ }^{10}$

\section{A megfelelően elemezhető adatmennyiség megszerzéséhez}

autóval megtett 3 milliárd mérföld elérése szuikséges.

Az ügyfelek által választott technológiák szerint az eszközök által rögzített adatok lehetnek egyszerűbbek (dátum, idő, lokáció, távolság) és komplexebbek (sebesség, sávváltás, gyorsítás, lassítás) egyaránt. A telematikai típusú termékek használata közben az ügyfelek számos bizalmas, privát adatot osztanak meg és engednek rögzíteni magukról, ami nem egyformán érzékenyen érinti őket. Az Egyesült Államokban is a többi piacon általánosan tapasztalt jelenség figyelhető meg, vagyis az 50 éves kor feletti ügyfelek jobban odafigyelnek a személyes adataik felhasználására, míg a fiatalabb korosztályok képviselői kevésbé aggódnak a személyes adataik megosztása és felhasználása miatt.

A megfelelő adatmennyiség összegyüjtése kulcsfontosságú feltétele a díjazás hatékony kiszámításának. A Deloitte amerikai szakértőinek elemzései alapján a megfelelően elemezhető adatmennyiség megszerzéséhez autóval megtett 3 milliárd mérföld elérése szükséges, ami a kisebb biztosítótársaságok számára újabb korlátokat állít a termék hatékony használata elé. Bár az akadály leküzdése felé tett lépésként megfigyelhető, hogy a kisebb biztosítók együttmüködnek a szükséges megtett mérföldekből származó tapasztalatok összegyűjtésében, a hatékonysághoz megkívánt 3 milliárd mérföldből származó információ elérése után kiemelten fontos szempont marad az adatgyűjtés, az elemzés és az értékelés választott módszertana is.

Az USA piacán elsőként a Progressive mutatta be használatalapú technológián alapuló gépjármű-biztosítási termékét 2011 márciusában, amely egy vezeték nélküli, OBD-II felülethez csatlakoztatható berendezésen alapul. A Snapshot elnevezésű termékével úttörőnek számító Progressive az amerikai piac negyedik legnagyobb gépjármü-biztosító társasága, amely jelenleg 45 államban és a fővárosban kínálja telematikai termékét. A Progressive kizárólag a Snapshot által 3 millió felhasználót ${ }^{11}$ és 2 milliárd dolláros ${ }^{12}$ díjbevételt ért el. A SnapShot legújabb, mobil alkalmazáson keresztül futó változatát a Progressive 2015-ben jelentette be, amelyet a 2016-os év során tervez forgalomba hozni, és fontos újítása a GPS funkció lesz. A jelenlegi Snapshot verzió esetében a vezetésről gyüjtött adatokat a biztosító nem osztja meg harmadik személyekkel, és csak az ügyfél által adott engedéllyel használja fel az esetleges kárrendezési folyamat során.

A Snapshothoz hasonlóan az Allstate szintén 2011-ben piacra dobott DriveWise elnevezésű terméke is olyan berendezést alkalmaz, amelyet az autók műszerfalán kialakított felülethez kell csatlakoztatni. A 28 államban elérhető DriveWise esetében azonban már egy mobil alkalmazást is igénybe lehet venni, amelyen keresztül a napi vezetéssel töltött idő, a sebesség és a fékezési adatok felhasználásával elemzett vezetési profilt lehet nyomon követni. A termékkel a kezdeti 10 százalék után minden hatodik hónap vezetési adatai alapján további 20 százalékos díjkedvezményt lehet elérni. ${ }^{13}$

A State Farm „Drive Safe and Save” ajánlata az előző két terméktől eltérően olyan külsős szolgáltatók által fejlesztett megoldásokkal együtt működik, mint az eleve az autókba telepített rendszerek (OnStar, SYNC), illetve berendezések (Verizon In-Drive terméke). Az autóba telepített berendezéseken kívül az ügyfelek választhatnak mobil applikációs megoldást is. A 2011-ben bemutatott és 8 államban elérhető termékkel - egyes államok szabályozása által okozott kivételekkel -, valamint számos egyéni körülmény figyelembevételével a kezdeti 5 százalék után a maximálisan elérhető díjkedvezmény akár 50 százalékos is lehet. ${ }^{14} \mathrm{~A}$ State Farm termékével már az egyre erősödő, autókba integrált rendszerekkel kommunikáló és mobil alkalmazás alapú telematikai megoldásokkal szembeni fogyasztói igényekhez próbál alkalmazkodni. 


\section{Európai áttekintés}

Az Európai Unió 25 tagállamának 2011-ben mért adatok alapján hozzávetőlegesen 241 millió személygépjárművel ${ }^{15}$ rendelkező piacán elsőként a nagyobb nyugat-európai központtal rendelkező biztosítótársaságok kezdték el saját használatalapú biztosítási termékek fejlesztésére irányuló programjukat. A 2013 júliusában mért 2,1 millió ügyféllel szemben 2015 novemberében már 4,4 millió ügyfél rendelkezett telematikai típusú gépjármü-biztosítással, akik többnyire az olasz, angol, spanyol és francia piacokról származnak. ${ }^{16}$ A Berg Insight adatai alapján az európai uniós telematikai piac évi 42,4 százalékos átlagos növekedést prognosztizálva 2019-re 28,1 millió darab szerződést fog elérni. ${ }^{17}$

Az Európai Unió 28 tagállama közül elsősorban a nyugat-európai országok biztosítási piacain, azon belül is Olaszországban és Nagy-Britanniában terjedtek el leginkább a használatalapú gépjármü-biztosítási termékek. Az olasz és a brit telematikai piac fejlettségét segítette elő az is, hogy Európában ezeken a biztosítási piacokon jelentek meg először a telematikai típusú termékek, az előbbi esetében 2003-ban, míg az utóbbinál 2007-ben. A telematikai termékek megjelenése elött mindkét piacon - többnyire a biztosítási csalások és az autólopások magas számának köszönhetően - magas gépjármü-biztosítási díjak voltak jellemzőek, amelyekre a gépjármü-tulajdonosok a használatalapú biztosítási termékek segítségével elért alacsonyabb díjakkal és autólopás elleni védelemmel egyszerre tudtak megoldást találni.

A nagyobb nyugat-európai piacok biztosítótársaságainak számos kihívással (üzleti modell, technológiai megoldás, marketingstratégia, az értékeléshez szükséges adatok, értékesítési csatornák és az ügyféladatok biztonsága) kell szembenézniük annak érdekében, hogy a telematikai típusú biztosítási termékeik minél könnyebben el tudjanak terjedni az adott piacon. A telematikai termékek elterjedését segítette elő, és a későbbiekben is elősegítheti az Európai Bíróság 2011-es ítélete ${ }^{18}$, amelyben kijelentették, hogy a női és férfi ügyfelek esetében is ugyanazokat a számításokat kell alkalmazni a díjak és juttatások meghatározásakor, ezért nemi alapon nem lehet különböző biztosítási kockázatot kalkulálni.

\section{A telematikai típusú biztosítási termékek esetén Európában \\ az úgynevezett „black box” vált a legelterjedtebbé.}

Az ilyen és az ehhez hasonló jövőbeni, ügyfélkockázati besorolásnál korábban figyelembe vett tényezőket korlátozó döntések várhatóan egyre inkább a használaton és vezetési teljesítményen alapuló tényezők figyelembevételére fogják a biztosítókat kényszeríteni az ügyfelek kockázati profiljának meghatározásakor. Az Európai Parlament az Európai Bizottság 2013. júniusi javaslata alapján született döntése szerint 2018 márciusától minden újonnan gyártott gépjármű esetében a közúti balesetek esetén automatikusan működésbe lépő e-segélyhívó (e-Call) beépítését tette kötelezővé, amely súlyos baleset esetén automatikusan tárcsázza a 112es közös európai segélyhívószámot. ${ }^{19}$ Mivel ennek a funkciónak az ellátásához a telematikai biztosítási termékekhez biztosított készülékekhez hasonló berendezések telepítése szükséges, ezért ez a folyamat is teret nyithat a használatalapú biztosítási termékek gyorsabban növekvő igénylése előtt.

A telematikai típusú biztosítási termékek esetén a hozzájuk kínált gépjárműbe szerelendő mérőeszközök közül Európában az úgynevezett „black box” vált a legelterjedtebbé, ugyanis ez az eszköz alkalmas többek között az eCall, a baleset-megelőzési, illetve a csalás és lopás elleni védelemhez kapcsolódó alkalmazások használatára is.

\section{Olaszország}

A korábban említettek alapján Európában az olasz piacon jelent meg az első használatalapú gépjármü-biztositási termék, amelyet 2003-ban a SARA Assicurazioni biztosítótársaság kezdett el értékesíteni.

A gépjármü-biztosítási termékek között 2015-ös becslések alapján 15 százalékot elérö ${ }^{20}$ telematikai díjbevétel penetrációjának, illetve a telematikai termékek elterjedtségének, valamint a hozzájuk kapcsolódó szolgáltatások fejlettségének szempontjából Olaszország tekinthető a legelőrehaladottabb használatalapú gépjármű-biztosítási piacnak Európában. A Berenberg becslése szerint az olasz piacon már több mint 2 millió olyan személygépjárművet tartanak számon, amelyekbe telematikai típusú termékhez kapcsolódó eszközök vannak telepítve. ${ }^{21} \mathrm{~A}$ jelenlegi piaci elterjedtség olyan fordulópontot jelenthet a piacon, amely után a hagyományos gépjármű-biztosítással rendelkező ügyfelek is a telematikai típusú - és ezzel az autó használatának alapján számított díjazású - termékek felé fognak fordulni annak érdekében, hogy elkerüljék a biztosítók által magas kockázatú ügyfél kategóriába történő automatikus besorolást. ${ }^{22}$

A használatalapú gépjármü-biztosítási termékek iránti olasz kereslet hátterét jól mutatja a Forrester Research nyugat-európai internethasználó felnőttek körében végzett felmérése is, amelynek alapján a spanyolok után az olasz megkérdezettek bizonyultak a legnyitottabbnak arra, hogy használatalapú gépjármű-biztosítást kössenek: a megkérdezettek mintegy 25 százaléka nyilatkozott úgy, hogy szívesen vásárolna telematikai típusú gépjármű-biztosítási terméket a közeljövőben. ${ }^{23} \mathrm{~A}$ Towers Watson 2013. szeptemberi felmérése szerint is az olaszok telematikai termékek iránti lelkesedését mutatja a megkérdezett autóvezetők részéről mért 75 százalékos érdeklődési arány a telematikai termékek iránt. ${ }^{24}$

Helyi piaci szakértők szerint a telematikai termékek olasz piacon tapasztalható kiemelkedő népszerűségének hátterében az áll, hogy az olasz biztosítók az úgynevezett „niche” szegmensekre fókuszáló termékek helyett egyszerü, alacsony költségü, az átlag szegmenseknek szánt termékeket kínálnak, illetve a különböző szegmenseknek nyújtott eltérő árazási kedvezmények számítása helyett a kárrendezések esetében is elkezdték kiaknázni az összegyüjtött adatokban rejlö lehetőséget. A termékek egyszerű struktúrája segítséget jelent az értékesítési hálózat számára is, ugyanis a könnyebben megérthető termékstruktúrákat hatékonyabban tudja ajánlani az ügyfeleknek. ${ }^{25}$ 
Szabályozás tekintetében is az olasz piac tekinthető élenjárónak. A korábban említett, európai szintű szabályozások mellett Olaszországon belül is születtek olyan szabályozói döntések, amelyeknek köszönhetően a használatalapú gépjármü-biztosítások iránti fogyasztói kereslet növekedése fenn tudott maradni. Ilyen jelentős hatású döntés volt 2012 áprilisában az olasz kormány ún. „Salva Italia” rendelete, amely a világon elsőként írta elő kötelezően a biztosítók számára, hogy alacsonyabb díjat kell ajánlaniuk azon ügyfelek számára, akik rendelkeznek az autójukba szerelt telematikai berendezéssel.

Az olasz piac legjelentősebb, használatalapú termékeket kínáló szereplői a Generali, az Unipol Group és az AXA Italia.

A Generali 2006-ban az elsők között indította el használati alapú gépjármü-biztosítási programját, amelynek eredményeként 2010 óta kínál a piacon telematikai termékeket. ${ }^{26}$ Ennek köszönhetően 2015-ben a biztosítótársaság már 800 ezer telematikai típusú biztosítási szerződéssel rendelkezett ${ }^{27}$, és a Genertellel közösen az új szerzés 33 százaléka telematikai termékekhez köthető. ${ }^{28}$ Saját elmondásuk szerint a sikerük titka abban is rejlett, hogy hosszú távú vezetési szokások elemzésének eredményén kívül az internetes felületen vagy a mobil alkalmazásukon keresztül más egyéb információkat is megosztanak az ügyfelekkel (útminőség, ajánlott vezetési stílus az adott útviszonyok között stb.). ${ }^{29}$ A Generali direktbiztosítója (Olaszországban a Genertel) által elsőként kínált „pay how you drive” termék, a „Quality Driver Program” segítségével akár 25 százalékos díjkedvezményt is el lehet érni. A black box („Quality Driver Box”) által összegyüjtött adatok alapján meghatározott minősítésük alakulását az ügyfelek akár internetes felületen, akár mobil alkalmazáson keresztül is figyelemmel kísérhetik.

Az AXA Olaszországban „Autogiov@ni Protection” elnevezésű termékét kínálja a 26 év alatti fiatalok számára, akik a műholdas berendezés által gyűjtött adatokat és az azokból kirajzolódó vezetési profiljukat a Bonux Online felületen tudják figyelni.

Az Unipol Assicurazioni az Unipol Group biztosítótársasága, amely a gépjármü-biztosítások terén a piacvezető biztosítók közé sorolandó Olaszországban. Az OCTO Telematikai közreműködésével indult sikeres, 2003-as fejlesztés eredményeként 2005-ben Unibox néven mutatta be telematikai termékét. Az Unibox egy műholdas black box eszköz segítségével gyűjti össze és elemzi ki a releváns vezetési adatokat, amelyek eredményét az ügyfelek egy online felületen tudják megtekinteni. Az Unibox segítségével az autótulajdonosok 5-től 30 százalékig terjedő díjkedvezményt tudnak elérni.

\section{Egyesült Királyság}

Európában az olasz biztosítási piac után 2007-ben a brit piac volt az, ahol az első szereplő, a Norwich Union (mai nevén Aviva) elkezdett telematikai típusú biztosítási terméket értékesíteni, illetve fejleszteni. Azóta a brit biztosítási piac tekinthető a leggyorsabb ütemben fejlődő telematikai piacnak az egész világon. 2007-re az úttörő olasz piacon már számos telematikai szolgáltató kínálta fejlesztéseit, amelyek könnyen adaptálhatók voltak, ezért a brit piacon is hasonló megoldások terjedtek el. Bár a szimplán telefonos alkalmazásokon alapuló telematikai termékek is elérhetőek, az Egyesült Királyságban elsősorban mégis a biztosítók által telepített eszközökkel együtt értékesített termékek váltak a legnépszerübbé. A British Insurance Brokers' Association (BIBA) 2016. márciusi adatai alapján az Egyesült Királyság biztosítási piaca 2015 végén 455 ezer darab élő telematikai „black box” szerződéssel rendelkezett, ami 40 százalékos növekedést jelent az előző évhez képest. ${ }^{31}$

Annak ellenére, hogy felmérések alapján Európában a spanyolok mellett a brit internethasználó felnőttek fejezték ki leginkább az aggodalmukat az iránt, hogy a használatalapú termékek alkalmazása díjnövekedést eredményezne a tradicionális gépjármü-biztosításukhoz képest ${ }^{32}$, az Egyesült Királyságban egy 2013-as felmérés szerint a brit autóvezetők 50 százaléka érdeklődik a telematikai termékek iránt. ${ }^{33}$

Az okostelefonokhoz kapcsolódó technológiák lehetővé tették a telematikai termékek népszerüségének növekedését és elterjedését.

A 2000-es évek közepén kínált használatalapú biztosítási termékek a hozzájuk tartozó berendezések autókba szerelésének időigénye és magas költsége miatt nem voltak túl népszerűek, és csak úgynevezett „niche” piaci termékként értékesítették őket. Az okostelefonokhoz kapcsolódó technológiák és az azok által eredményezett gyorsabb és költségkímélőbb telepítési procedúrák 2010-től lehetővé tették a telematikai termékek népszerüségének növekedését és elterjedését, elsősorban a fiatalabb korosztályok körében. A Towers Watson által 2013-ban készített felmérés szerint a brit fiatalok a többi európai országhoz képest a legnagyobb arányban fejezték ki érdeklődésüket a telematikai termékek iránt. ${ }^{34} \mathrm{~A}$ magas kockázati besorolásnak köszönhetően ugyanis a húszas éveikben járó, kevés vezetési tapasztalattal rendelkező autóvezetők a használatalapú gépjármü-biztosítási termékek megjelenése és elterjedése előtt jelentős biztosítási díjakat voltak kénytelenek fizetni, amelyeket a telematikai termékek megvásárlása után a balesetmentes közlekedéssel jelentősen tudtak csökkenteni. A Norwich Union által a 2000-es évek közepén közzétett statisztikák szerint a telematikai termékek hatására jelentősen csökkent az azt használó fiatal soförök által okozott káresetek száma, ugyanis az elemzések szerint a 18 és 23 év közötti ügyfelek esetében 20 százalékkal alacsonyabb volt a valószínűsége annak, hogy baleset résztvevői lesznek, mint a nem telematikai termékkel rendelkező kortársaik esetében. ${ }^{35}$

A brit biztosítási piacon néhány erre specializálódott szereplö, mint az Insurethebox, a Coverbox, illetve néhány tradicionális biztosító, mint az Aviva és a Direct Line Group kínálnak használatalapú gépjármü-biztosításokat réspiaci termékként.

A korábbi black box eszközzel értékesített termék újításaként 2012-ben az Aviva bemutatta Aviva Drive elnevezésű fejlesztését, amely egy mobil alkalmazást takar, amelyet minden jelenlegi és új, klasszikus gépjármü-biztositással rendelkező ügyfelük igénybe vehet. Az alkalmazás használatával minimum 200 mérföld megtétele után az évi 400 fontot meghaladó biztosítási díjat fizetö ügyfelek értékelésük függvényében akár 28 százalékos díjkedvezményt is el tudnakérni. 
A brit telematikai piac egyik legjelentősebb szereplője a Direct Line Group, amely az Egyesült Királyság vezető gépjármű-biztosítójaként a regisztrált gépjárművek körülbelül 20 százalékát biztosítja. A 2014-ben bemutatott black box típusú eszközt, amelyet a DrivePlus nevű telematikai termékéhez biztosít, az ügyfeleknek maguknak kell telepíteniük. Az eszköz által összegyűjtött adatok alapján kirajzolódó vezetési profilt a kapcsolódó mobil alkalmazáson, illetve internetes felületen keresztül lehet követni. A DrivePlus-t 26 éven aluli ügyfeleknek ajánlják, akik 21 éves kor alatt 25 százalékos induló díjkedvezményt kapnak, amely a 21-25 éves korosztályok számára sem lehet alacsonyabb 15 százaléknál. ${ }^{36}$

2009-es indulása óta a Coverbox az Egyesült Királyság egyik vezető használatalapú gépjármü-biztosítója lett. Sikerének egyik alapja egyedi üzleti modellje, amelynek alapján a Coverbox termékének igénybevételekor az ügyfelek más vezető biztosítók (Highway Insurance, Aviva, Zurich) termékei közül választhatnak. Ha az ügyfelek nem teljesítik a más biztosítók termékeiben foglalt, az elvárt megtett távolságra, illetve a vezetés időszakára vonatkozó elvárásokat, akkor a Coverbox megtéríti nekik a fizetendő extra díjat. A termékhez tartozó black box eszköz autókba történő beszerelését a Coverbox vállalja, majd a beszerelés után az ügyfelek saját internetes felületen keresztül követhetik vezetési profiljukat. ${ }^{37}$

Az Insure The Box telematikai terméke esetében a Clear box elnevezésü black box eszköz beszerelése után fix távolság megtételére terjed ki a biztosítás, és az ügyfél a vezetési stílustól függően extra biztosított kilométereket kaphat.

\section{Spanyolország}

A 2008-as pénzügyi válság negatív hatásai Spanyolország gazdaságát, illetve biztosítási szektorát is jelentősen érintették. Az ügyfelekért folytatott küzdelemben ezért a biztosítók elkezdtek egyre inkább az olyan innovatív megoldások felé fordulni, mint a használatalapú gépjármű-biztosítások, amelyek segítségével könnyebben meg tudják különböztetni termékeiket a piac más szereplőiétől. A Towers Watson 2013. szeptemberi felmérése szerint más európai társaikhoz képest a spanyol autóvezetők mutatják a legnagyobb hajlandóságot arra, hogy akár több biztosítási díjat is fizessenek hozzáadott értéket adó szolgáltatásokért. A felmérés alapján a megkérdezett autóvezetők 69 százaléka mutatott érdeklődést a telematikai termékek iránt. ${ }^{38} \mathrm{~A}$ telematikai típusú termék elterjedését elősegíti az is, hogy a spanyol piac tekinthető a legnyitottabbnak arra, hogy a telematikai termékeket egyszerü mobil alkalmazásokként is értékesítsék az autóba szerelendő berendezés nélkül.

A spanyol piacon a MAPFRE számít úttörőnek a használatalapú gépjármü-biztosítások fejlesztése terén, ugyanis a vezető spanyol biztosító volt az első, amely a 2007 óta végzett fejlesztések után 2009-ben bemutatta YCar elnevezésű telematikai termékét. Az YCar egy olyan új biztosítási modellt kínál a magasabb kockázati kategóriába tartozó 18-30 éves ügyfelek számára, amely jutalmazza az óvatosabb vezetési stílust, ezzel hozzájárulva a biztonságosabb közlekedéshez. A termék díjkedvezményt kínál a szerződés aláírásakor, és 1 év után további kedvezményeket nyújt a megtett távolság és a vezetési stílus függvényében, ami akár 40 százalékos díjcsökkenést is jelenthet. A MAPFRE YCAR termékével 2009 és 2013 között 80 ezer új, a terméket igénybe vevő 18 és 30 év közötti ügyfelelet tudott szerezni. ${ }^{39}$

A Generali Seguros, a Generali-csoport spanyol leánya tekinthető a másik olyan szereplőnek, aki az elmúlt években aktívnak bizonyult a használatalapú biztosítási termékek fejlesztése terén. A Generali a spanyol telekommunikációs vállalattal, a Telefónicával közösen fejlesztett "pago como conduzco" termékét 2013 elején mutatta be. A termékhez egy „machine-to-machine” (M2M) berendezést kínálnak, amely az autókba szerelve gyüjti az olyan adatokat, amelyek alapján a megtett távolság, a nappali vagy éjszakai vezetés, a városi vagy városon kívüli közlekedés, a sebességhatárok betartása, illetve a gyorsítás és lassítás figyelembevételével kalkulálják ki a fizetendő díjat.

A berendezés által gyűjtött adatokat és a vezetési szokás alapján alkotott vezetői profilt az ügyfelek a kapcsolódó mobil alkalmazáson és az internetes felületen tudják követni. Az ügyfelek a kezdeti egyszeri díjkedvezmény után az YCAR-hoz hasonlóan ezzel a termékkel akár 40 százalékos díjkedvezményt is el tudnak érni.

\section{Németország}

Mivel a gépjármü-biztosítások díja, valamint a gépjárműlopások és a biztosítási csalások száma jelenleg is alacsonynak mondható, a német piacon eddig sem a biztosítók, sem pedig a gépjármű-tulajdonosok részéről nem mutatkozott számottevő érdeklődés a használatalapú gépjármü-biztosítások iránt. Ez persze nem jelenti azt, hogy a piaci szereplők ne próbálkoznának a használatalapú termékek fejlesztésével és piacra való bevezetésével. A német piac a fejlett közlekedési és gépjárműipari kultúrája miatt vonzó célpontot jelent a telematikai szolgáltatók számára is, azonban szakértők szerint nehezíti a helyzetet, hogy a német jogi szabályozás elég bonyolult, túl sok jogszabálynak kell megfelelni, és azok többnyire nagyon szigorúan védik a fogyasztók érdekeit, illetve személyes adatainak biztonságát. ${ }^{40} \mathrm{Az}$ adatvédelem a német gépjárműsoförök számára ugyanis az átlagosnál fontosabb szempont.

A Towers Watson 2013-as felmérése alapján is elmondható, hogy a személyes adatok védelme Németországban több korcsoport számára inkább kiemelt fontosságú, mint a többi vizsgált nyugat-európai ország esetében. ${ }^{41} \mathrm{~A}$ német piacon a legtöbb nyugat-európai piactól eltérően a különböző korosztályú ügyfelek által fizetendő gépjármü-biztosítási díjak között nincs jelentős különbség. A német piac sajátossága az is, hogy nemcsak a 18 és 30 év közötti korosztályok, hanem a 65 év felettiek is kiemelt érdeklődést mutatnak a telematikai típusú termékek iránt, és a 65 év feletti korosztály tagjai ugyancsak egyedülálló módon azon csoportok közé tartoznak, akik a legkevésbé aggódnak a személyes adataik védelme miatt. 
Németországban az úttörő olasz és a legdinamikusabban növekvő brit piacoknál néhány évvel később, csak 2014-ben jelent meg az első használatalapú gépjármű-biztosítási termék, amelyet a Sparkassen Direktversicherung kezdett el értékesíteni. A Sparkassen Direktversicherung az egyik tartományi biztosító, a Provinzial Rheinland direktbiztosítója, amely a már korábban említett, telematikai fejlesztések terén aktív spanyol telekommunikációs vállalat, a Telefónica német leányával közösen fejlesztette ki „Telematik-Sicherheits-Service” elnevezésű ajánlatát a német autóvezetők számára. A vezetésről szükséges adatokat a termékhez kínált autókba szerelendő berendezés gyüiti össze, amelyekhez a szigorú adatvédelmi szabályoknak megfelelően csak az autóvezető férhet hozzá, a biztosító csak aggregált adatokat kap a vezetésről, illetve a megtett kilométerről.

\section{A német piac megkülönböztető jegye, hogy a biztosítóknak fi- gyelemmel kell kísérniük a három nagy német autógyártó által követett telematikai stratégiát is.}

A német piac legfőbb megkülönböztető jegye, hogy a helyi biztosítóknak telematikai stratégiájuk kialakítása során figyelemmel kell kísérniük a három nagy német autógyártó (Volkswagen-csoport, BMW és Mercedes) által követett telematikai stratégiát is, mivel az autógyártókkal történő együttműködés során sokkal részletesebb és értékesebb adatokat tudnak összegyűjteni az autót használók vezetési szokásairól. Ennek az együttműködési törekvésnek az első jeleként lehet tekinteni az Allianz és a Volkswagen által 2013-ban alapított közös vállalatra, a Volkswagen Autoversicherung AG-ra, amely egyelöre csak klasszikus gépjármü-biztosításokat értékesít. ${ }^{42}$

Az Allianz és a BMW között 2014-ben létrejött gépjármü-biztosítási együttműködési megállapodás már a német biztosítók és az autógyártók közötti együttműködés újabb szintjét jelenti. A megállapodás értelmében a BMW újonnan gyártott elektromos autóiba már a gyártás során beépítik a telematikai funkciót, amely kizárólag a gépjármű-tulajdonos által az Allianz gépjármü-biztosítási termékének igénylésekor aktiválható. A BMW i3 és i8 modellek megvásárlása után az ügyfél a biztosítás 7 napos ingyenes használatára jogosult, majd ezután igény esetén a BMW Car Insurance meglévő termékei mellett megvásárolhatja a BMW által újonnan gyártott elektromos autókhoz kínált Allianz telematikai termékeket: a Flexi Mile-t - amely az évi maximum 5000 kilométert vezető soföröknek biztosít automatikusan 25 százalék díjkedvezményt - és az évi 5000 kilométernél többet vezető soföröknek fix díjért kínált Unlimited Mile-t is. ${ }^{43}$

Az Allianz Németország egyik legnagyobb gépjármü-biztosítójaként természetesen nem csak a BMW-vásárlók számára kínál használatalapú gépjármű-biztosításokat. Legújabb ilyen terméke a kanadai UBI szolgáltató, az Intelligent Mechatronic Systems (IMS) segítségével fejlesztett BonusDrive. A 28 éves kor alatt igénybe vehető BonusDrive mobil applikáción alapszik, amelyen a hozzá kapcsolódó, 12 voltos Bluetooth adapter által begyüjtött vezetési információkat lehet követni. A termékkel 10 százalék kezdeti dijkedvezményt lehet elérni, amely a kockázatmentes gépjármühasználat során további 30 százalékkal növelhető. ${ }^{4}$

A tartományi biztosítókon és az ország legnagyobb biztosítóján, az Allianzon kívül más szereplők is elkezdtek az innovatív megoldások, többek között a telematikai típusú fejlesztések felé nyitni. Ezek közül az egyik legjelentősebb fejlesztés a telematikai termékek fejlesztése terén más országokban is aktív AXA-hoz köthető. A francia biztosító 2015-ben mutatta be DriveCheck elnevezésű, használatalapú gépjármü-biztosítási termékét a német piacon. A 26 éven aluliaknak kínált és az „AXA Drive” mobil applikáción keresztül működő termékkel a fiatal soförök a regisztrációtól számított 12 héten belül mért vezetési adatok alapján 5 -től 15 százalékig terjedő díjkedvezményt érhetnek el.

Összességében a német telematikai típusú gépjármü-biztosítási piacról elmondható, hogy a korábbi nyugat-európai példákhoz képest ugyan néhány évvel később, de a külföldi biztosítók német leányainak, néhány nagyobb hazai biztosítónak és a nagy német autógyártóknak köszönhetően a szigorúbb adatvédelmi előírások ellenére egyre aktívabbak kezdenek lenni a biztosítási szereplők és ügyfelek is. A piaci és az ügyféligényeknek megfelelően a német piacon a mobil alkalmazás alapú termékek örvendenek nagyobb népszerűségnek, amit az elmúlt 1-2 év számos új fejlesztése is jól bizonyít. Az ügyfelek többsége a telematikai termékek alacsony népszerüségének és elterjedtségének ellenére számos felmérés szerint is nyitott ezekre az új megoldásokra, különösen akkor, ha ez többletszolgáltatásokkal és alacsonyabb díjakkal párosul. 


\section{HIVATKOZÁSOK}

' Ptolemus Consulting Group. Usage-based insurance global study, October $2013^{2}$ cliquet-style option ${ }^{2}$ Ptolemus Consulting Group: Global Usage-based Insurance Study, January 2016

${ }^{3}$ Sam Friedman, Michelle Canaan , „Overcoming speed bumps on the road to telematics. Challenges and opportunities facing auto insurers with and without usage-based programs", Deloitte University Press, 2014

"Telefonon lefolytatott interjú Sandeep Purival, Consulting Managing Director (Deloitte New York)

'Telefonon lefolytatott interjú Sandeep Purival, Consulting Managing Director (Deloitte New York)
${ }^{S}$ Sam Friedman, Michelle Canaan, „Overcoming speed bumps on the road to telematics. Challenges and opportunities facing auto (1)

${ }^{7} \mathrm{Az}$ UNIQA Biztositó interjúnk készitése óta felfüggeszztette a termék értékesitését, tehát jelenleg nem elérhetỏ ez a szolgáltatás, jelenleg is keresik a jövőbeni hatékonyabb megoldási lehetöségeket.

"Catherine Stagg-Macey, "Telematikai-Based Insurance: Has Its Time Finally Arrived?" Cel

January 2012, http://www.celent.com/reports/telematikai-based-insurance-has-its-time-finally-arrived.

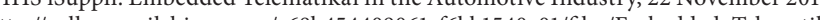

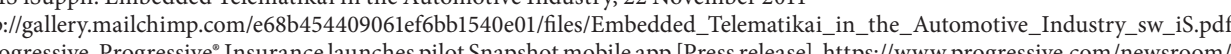
article/2015/september/snapshot-mobile-app/ ${ }^{13}$ Allstate: Drivewise"
${ }^{1}$ FAQ

"State Farm. That's You With Drive Safe \& Save". https://www.statefarm.com/insurance/auto/discounts/drive-safe-save/

${ }^{15}$ Berg Insight, Insurance Telematikai in Europe and North America

"Berg Insight. Insurance Telematikai in Europe and North America

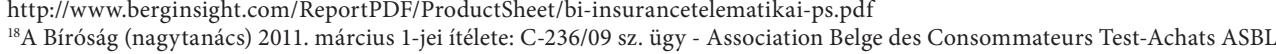

és társai kontra Conseil des ministres
${ }^{19}$ Európai Bizottság. ECall in all new cars from April 2018, 28 April 2015

https://ec.europaen /digital-single-market/en/n

${ }^{20}$ Matteo Carbone: Insurance Telematikai is not (only) UBI, Uniglobal Events, 21 October 2015

https://www.linkedin.com/pulse/insurance-telematikai-only-ubi-matteo-carbone

${ }^{21}$ Berenberg. The rise of the machines, 11 June 2013

https://www.berenberg.de/fileadmin/user_upload/berenberg2013/02_Investment_Banking/Equity_Research/2013_06_12_the_

art 21 March 2014

http:///analysis.tu-auto.com/insurance-telematikai/insurance-telematikai-europe-tipping-point-near-part-i
${ }^{23} \mathrm{E}$ Ilen Carney and Aurelie L'Hostis: Europeans are ready for usage-based car insurance, 18 February 2015, Forrester Research ${ }^{24}$ Towers Watson: Telematikai: what European consumers say, September 2013

${ }_{25}^{25}$ Matteo Carbone: Insurance Telematikai is not (only) UBI, Uniglobal Events, 21 October 2015

https://www.linkedin.com/pulse/insurance-telematikai-only-ubi-matteo-carbone

${ }^{27}$ Ptolemus Consulting Group:

${ }^{28} \mathrm{Alberto}$ Grassani: Italy's Generali acquires MyDrive Solutions, a leading UK start-up in motor insurance technologies, 24 July 2015

http://www.italy24.ilsole24ore.com/art/markets/2015-07-23/generali-133845.php?uuid=ACKPfIW

Jan Stojaspal: Insurance telematikai business models: Beyond the discount, 13 August 2013

New Auto Insurance Products and a New Industry Ecosystem, September 2012

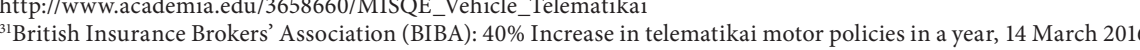

${ }^{32}$ https://www.biba.org.uk/latest-news/40-increase-in-telematikai-motor-policies-in-a-year/

${ }^{32}$ Forrester's European Consumer Technographics Financial Services Survey 2, 2014
${ }^{3}$ Towers Watson: Telematikai: what European consumer say September 2013

${ }^{34}$ Towers Watson: Telematikai: what European consumer say, September 2013

${ }^{35}$ Carlo Palmieri: Telematikai trends in the UK:

http://www.the-digital-insurer.com/telematikai-insurance-uk/
${ }^{36}$ https://www.directline.com/car-insurance/telematikai

${ }^{37}$ Andrew Tolve. Insurance telematikai: Understanding the UK market, 2 June 2011

http://analysis.tu-auto.com/insurance-telematikai/insurance-telematikai-understanding-uk-market ${ }^{3}$ Towers Watson: Telematikai: what European consumers say, September 2013

http://analysis.tu-atto.com/nsurance-telematikai/nsurance-telematikai-europe-tipping-point-near-part-ii

${ }_{42}^{42}$ Towers Watson. Telematikai: what European consumers say September 2013

${ }^{43}$ Jon Martindale: Allianz to offer telematikai for BMW electric cars, 22 July 2014

http://www.telematikai.com/allianz-offer-telematikai-solution-bmw-electric-cars/

"thttps://www.allianz.de/auto/kfz-versicherung/telematik-versicherung/ 